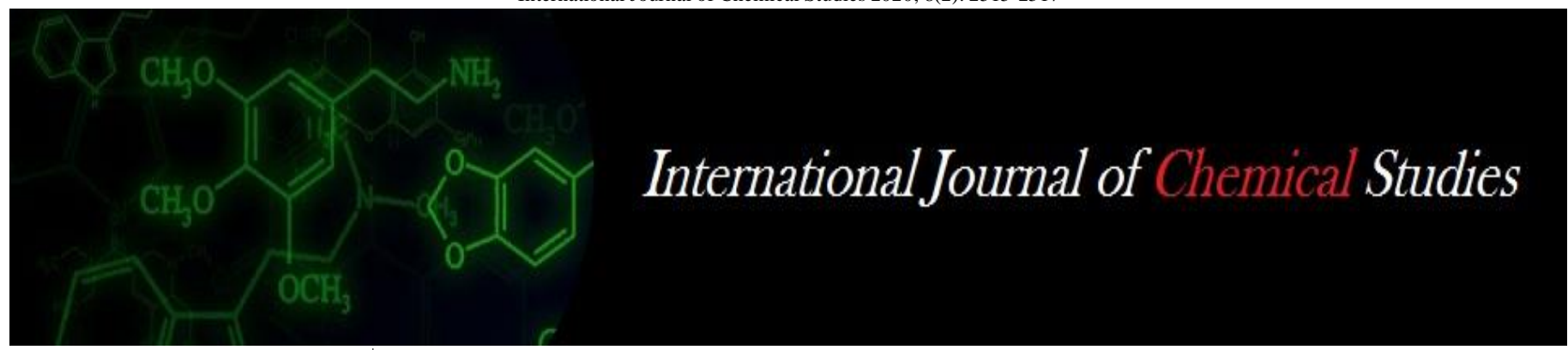

P-ISSN: 2349-8528

E-ISSN: 2321-4902

www.chemijournal.com

IJCS 2020; 8(2): 2515-2517

(C) 2020 IJCS

Received: 24-01-2020

Accepted: 26-02-2020

Shilpa Koushik

Indira Gandhi Agricultural

University, Raipur,

Chhattisgarh, India

BL Chandrakar

Indira Gandhi Agricultural

University, Raipur,

Chhattisgarh, India

Amit Kumar Shukla

Indira Gandhi Agricultural

University, Raipur,

Chhattisgarh, India

Corresponding Author:

Shilpa Koushik

Indira Gandhi Agricultural

University, Raipur,

Chhattisgarh, India

\section{Effect of integrated weed management practices on growth and yield of Direct Seeded rice under puddle condition of Agro-climatic situation of Chhattisgarh}

\author{
Shilpa Koushik, BL Chandrakar and Amit Kumar Shukla
}

DOI: https://doi.org/10.22271/chemi.2020.v8.i2al.9128

\begin{abstract}
The present investigation was conducted at Instructional Farm of Indira Gandhi Krishi Vishwavidyalaya, Raipur (C.G.) India during the kharif season (June-October) 2006. The experiment was laid out in randomized block design comprised of eight treatments of various combinations of different herbicides viz. $\mathrm{T}_{1}: \mathrm{PIH} 202310 \% \mathrm{SC} 15 \mathrm{~g}$ a.i/ha at $18 \mathrm{DAS} ; \mathrm{T}_{2}: \mathrm{PIH} 202310 \% \mathrm{SC} 20 \mathrm{~g}$ a.i/ha at $18 \mathrm{DAS} ; \mathrm{T}_{3}: \mathrm{PIH}$ $202310 \%$ SC $25 \mathrm{~g}$ a.i/ha at $18 \mathrm{DAS} ; \mathrm{T}_{4}$ : PIH 2023 10\% SC $30 \mathrm{~g}$ a.i/ha at $18 \mathrm{DAS} ; \mathrm{T}_{5}$ : PIH $202310 \% \mathrm{SC}$ $60 \mathrm{~g}$ a.i/ha at $18 \mathrm{DAS} \mathrm{T}_{6}$ : Almix 20\% WP $4 \mathrm{~g}$ a.i/ha $18 \mathrm{DAS} ; \mathrm{T}_{7}$ :Control (unweeded check) and $\mathrm{T}_{8}$ : Hand weeding at 30 DAS with three replications. Rice cultivar "IR-64" was grown as a test crop. The growth performance of Rice i.e. plant height, Number of tillers $\left(\mathrm{m}^{-2}\right)$, Number of effective tillers $\left(\mathrm{m}^{-2}\right)$, dry matter accumulation plant ${ }^{-1}$, was higher under PIH 2023 10\% SC $25 \mathrm{~g}$ a.i/ha as compared to other weed management practices. Wher as the minimum growth of rice recorded under unweeded. Maximum grain yield and straw yield was under PIH 2023 10\% SC 60 g a.i/ha Echinochloa colona, Cyperus spp., F. miliaceae, L. hyssopifolia were the pre-dominant weeds in experimental plot. Minimum weed density was noted under post emergence application of Almix $4 \mathrm{~g} \mathrm{ha}^{-1}$ and PIH $202325 \mathrm{~g} \mathrm{ha}^{-1}$ at 20, 40, 70 and 90 DAS. Whereas, at harvest lower dry matter of weeds and highest weed control efficiency was recorded under Almix $4 \mathrm{~g} \mathrm{ha}^{-1}$ (T6), PIH $202325 \mathrm{~g} \mathrm{ha}^{-1}$ and PIH $202360 \mathrm{~g} \mathrm{ha}^{-1}$, respectively. It was found effective to control broad spectrum of weeds viz., grasses, sedges and forbs.
\end{abstract}

Keywords: Integrated weed management practices, growth and yield of rice

\section{Introduction}

Rice (Oryza sativa L.) is important staple food crop occupying 42.4 million and 3.5 million hectare in India and Chhattisgarh recently. The average productivity of rice in Chhattisgarh is about $1.58 \mathrm{t} / \mathrm{ha}$, which is below the national average $(2.05 \mathrm{t} / \mathrm{ha})$.

The rice culture system in Chhattisgarh mainly depends on the onset and distribution of monsoonal rains. They can be broadly classified into three categories namely rice growing on upland situation mostly rainfed, medium land rice both in direct dry seeded broadcast "Biasi" and transplanting under protective irrigated conditions or both. Sometimes farmers are forced to adopt "Lehi" method. This situation arises when monsoonal rain continue for a longer period. Farmers are not in a position to adopt neither direct seeding nor transplanting. Rice is grown under conducive condition to profuse weed growth. As such during the early stages of crop growth, severe weed-crop competition is a big constraint for improving rice productivity. In the rice ecosystem of this region weeds play a dominant role by competing for nutrients, water and space with the rice crop. Based on research findings it was estimated that extent of yield reduction in rice due to weeds alone is about 15-20 per cent for transplanted rice, 30-35 per cent for direct seeded puddled rice and over 50 per cent in direct dry seeded rice.

Several herbicides such as butachlor, anilofos and pretilachlor, have been recommended for the control of weeds in rice which are effective on broad spectrum of rice weeds. Some herbicides like 2, 4-D controlled only broad leaf weeds. Further, these herbicides are required in large quantity, which will distort our ecosystem and increase chemical load to environment. Thus, for effective control of mixed weed flora. Evaluation of new herbicide with low 
application rate is required. Now-a-days herbicides are gaining popularity because of their selectiveness and effectiveness.

\section{Materials and methods}

The present investigation was conducted at Instructional Farm of Indira Gandhi Krishi Vishwavidyalaya, Raipur (C.G.) India during the kharif season (June-October) 2006. The experiment was laid out in randomized block design comprised of eight treatments of various combinations of different herbicides viz. $\mathrm{T}_{1}: \mathrm{PIH} 202310 \% \mathrm{SC} 15 \mathrm{~g}$ a.i/ha at $18 \mathrm{DAS} ; \mathrm{T}_{2}$ : PIH 2023 $10 \% \mathrm{SC} 20 \mathrm{~g} \mathrm{a.i} / \mathrm{ha}$ at $18 \mathrm{DAS} \mathrm{T}_{3}$ : PIH $202310 \% \mathrm{SC} 25 \mathrm{~g}$ a.i/ha at $18 \mathrm{DAS} ; \mathrm{T}_{4}$ : PIH $202310 \% \mathrm{SC} 30 \mathrm{~g}$ a.i/ha at 18 DAS; $\mathrm{T}_{5}$ : PIH $202310 \%$ SC $60 \mathrm{~g}$ a.i/ha at $18 \mathrm{DAS} \mathrm{T}_{6}$ : Almix $20 \%$ WP 4 g a.i/ha 18 DAS; $\mathrm{T}_{7}$ :Control (unweeded check) and $\mathrm{T}_{8}$ : Hand weeding at $30 \mathrm{DAS}$ with three replications. Rice cultivar "IR-64" was grown as a test crop. Rice was manually sown with a seed rate of $60 \mathrm{~kg} \mathrm{ha}^{-1}$ on $25^{\text {th }} \mathrm{July}$, 2006 and harvested on $15^{\text {th }}$ and $16^{\text {th }}$ November, 2006. The crop was fertilized with 100:60: $40 \mathrm{~kg} \mathrm{NPK} \mathrm{ha}^{-1}$, respectively.

\section{Result and discussion}

\section{Effect on growth}

The higher plant height was recorded under at harvest PIH $202310 \%$ SC $25 \mathrm{~g}$ a.i/ha as compared to other weed management practices of rice Significantly lower plant height was observed under unweeded. Higher plant height under these treatments were due to the fact that there was lower weed competition of weeds, which allowed rice to absorb required amount of nutrient and water for its growth. This favoured the higher plant height of rice. The maximum number of tillers $\mathrm{m}^{-1}$ was registered in PIH $202310 \%$ SC $25 \mathrm{~g}$ a.i/ha. Significantly higher dry matter accumulation plant ${ }^{-1}$ under PIH 2023 10\% SC $25 \mathrm{~g}$ a.i/ha, Followed by Almix 20\% WP $04 \mathrm{~g}$ a.i /ha, PIH 2023 10\% SC $15 \mathrm{~g}$ a.i/ha and PIH 2023 $10 \%$ SC $20 \mathrm{~g} \mathrm{a}$ i/ha were found at par with each other as to other weed management practices. Significantly lower dry matter production of soybean was observed under unweeded. Higher dry matter production under these treatments were due to lower weed competition, which allowed soybean to absorb required amount of nutrient and water for its growth. Higher dry matter accumulation also associated with the higher Number of tillers which supported the growth. The increased leaf area might have enhanced the photosynthesis due to which plant dry matter accumulation was higher under these treatments. Similar result were also reported by Narwal et al. (2002) ${ }^{[1]}$ and Chinnusamy et al. (2002) also reported the similar things.

The minimum number of tillers was recorded under unweeded control. On the other hand, the maximum number of tillers were recorded under PIH 2023 10\% SC $25 \mathrm{~g}$ a.i/ha and found significantly superior to rest of the treatment. And The minimum number of effective tillers was recorded under unweeded control. On the other hand, the maximum number of effective tillers were recorded under PIH 2023 10\% SC 20 $\mathrm{g}$ a.i/ha and found significantly superior to rest of the treatments the result are conformity with the finding by Gogoi (1998) and Rekha et al. (2003).

\section{Effect on yield components}

Panicle length was longest in post-emergence application of PIH $202315 \mathrm{~g} \mathrm{ha}^{-1}\left(\mathrm{~T}_{1}\right)$ followed by hand weeding once. The panicle length were similar to remaining dose of PIH 2023 like $20 \mathrm{~g} \mathrm{ha}^{-1}\left(\mathrm{~T}_{2}\right), 25 \mathrm{~g} \mathrm{ha}^{-1}$. The panicle length was statistically at par with other and unweeded check. Similarlythe maximum panicale weight under PIH $202315 \mathrm{~g}$ $\mathrm{ha}^{-1}\left(\mathrm{~T}_{1}\right)$ and minimum panical length was found unweeded check. the treatments proved significantly superior over unweeded control in increasing number of fertile grains panicle $^{-1}$. Among various treatments, highest (102.16) grains panicle $^{-1}$ were recorded under hand weeding once $\left(\mathrm{T}_{8}\right)$ followed by Almix $4 \mathrm{~g} \mathrm{ha}^{-1}\left(\mathrm{~T}_{6}\right)$ and PIH $202320 \mathrm{~g} \mathrm{ha}^{-1}\left(\mathrm{~T}_{2}\right)$. Lowest filled grains were recorded under unweeded check. Hand weeding once and different dose of PIH 2023 and Almix gave better results for filled grains panicle ${ }^{-1}$ and were superior over unweeded check.

PIH 2023 10\% SC $25 \mathrm{~g}$ a.i/ha produced maximum test weight and it was significantly superior to other weed management practices whereas lowest test was recorded under unweeded control. This was due to better suppression of weeds, more availability of nutrients, production of higher crop growth and favorable influence on sink capacity and its effective translocation towards the maximum grain and straw under PIH $202310 \%$ SC $60 \mathrm{~g}$ a.i/ha. These findings corroborate the report of (Tiwari, 2002) [2]

\section{Effect on yield}

The maximum grain yield was produced under PIH 2023 10\% SC $60 \mathrm{~g} \mathrm{a.i/ha} \mathrm{(48.91} \mathrm{q} \mathrm{ha}^{-1}$ ) as compared to other weed management practices. Whereas minimum seed yield was observed under unweeded control $\left(25.66 \mathrm{q} \mathrm{ha}^{-1}\right)$, which was significantly lower than rest of the treatments. This might be due to high growth and yield attributes as well as low cropweed competition under these treatments. High growth in terms of LAI produced large amount of photosynthetic which acts as source and helped in developed of high yield attributes. The capacity of plants to produce seed yield depends not only on the size of photosynthetic system, it's efficiently and length of the time for which it is active but also on translocation of dry matter in to the economic sink. The final build up of yield is the cumulative function of yield components. The results are conformity with the finding by Mane and Raskar 2002 Amongest weed management practice, PIH 2023 10\% SC $60 \mathrm{~g}$ a.i/ha produced the maximum Straw yield of $59.34 \mathrm{q} \mathrm{ha}^{-1}$ which was significantly superior to rest of the treatments. All the herbicides alone or in combination were significantly superior to unweeded control.

Table 1: Effect of different weed management practices on plant growth, tillers and dry matter of rice

\begin{tabular}{|c|c|c|c|c|}
\hline Treatment & Plant height $(\mathrm{cm})$ At harvest & $\begin{array}{l}\text { Number of tillers } \\
\left(\mathbf{m}^{2}\right) 70 \text { DAS }\end{array}$ & $\begin{array}{c}\text { Number of effective } \\
\text { tillers }\left(\mathbf{m}^{2}\right)\end{array}$ & $\begin{array}{c}\text { Dry matter of rice (g plant } \\
\text { 1) At harvest }\end{array}$ \\
\hline $\mathrm{T}_{1}$ : PIH $202310 \%$ SC $15 \mathrm{~g}$ a.i/ha & 92.00 & 445.33 & 341.67 & \begin{tabular}{|c|}
9.23 \\
\end{tabular} \\
\hline $\mathrm{T}_{2}:$ PIH $202310 \%$ SC $20 \mathrm{~g}$ a.i/ha & 96.17 & 513.33 & 401.00 & 9.07 \\
\hline $\mathrm{T}_{3}: \mathrm{PIH} 202310 \%$ SC $25 \mathrm{~g}$ a.i/ha & 97.80 & 536.33 & 388.00 & 11.10 \\
\hline $\mathrm{T}_{4}: \mathrm{PIH} 202310 \%$ SC $30 \mathrm{~g}$ a.i/ha & 91.60 & 480.00 & 391.33 & 8.43 \\
\hline $\mathrm{T}_{5}$ : PIH $202310 \%$ SC $60 \mathrm{~g}$ a.i/ha & 95.70 & 487.33 & 384.00 & 8.82 \\
\hline $\mathrm{T}_{6}:$ Almix $20 \%$ WP $04 \mathrm{~g}$ a.i $/ \mathrm{ha}$ & 91.43 & 478.67 & 359.00 & 10.30 \\
\hline $\mathrm{T}_{7}:$ Unweeded check & 93.27 & 453.33 & 307.33 & 5.27 \\
\hline $\mathrm{T}_{8}:$ Hand weeding (once) & 92.60 & 448.67 & 331.33 & 8.76 \\
\hline $\mathrm{SEm} \pm$ & 0.97 & 16.71 & 13.76 & 0.25 \\
\hline $\mathrm{CD}(5 \%)$ & 2.95 & 50.69 & 41.76 & 0.76 \\
\hline
\end{tabular}


Table 2: Effect of different weed management practices on panical length, yield attributes, yield and weed index of rice.

\begin{tabular}{|c|c|c|c|c|c|c|}
\hline $\begin{array}{c}\text { Treatment } \\
\end{array}$ & Panicle length $(\mathrm{cm})$ & Number of filled grains & Weed index (\%) & Test weight (g) & Grain yield (g/ha) & Straw yield (g/ha) \\
\hline $\mathrm{T}_{1}$ : PIH $202310 \%$ SC $15 \mathrm{~g}$ a.i/ha & 24.56 & 86.30 & 9.41 & 22.57 & 41.48 & 47.01 \\
\hline $\mathrm{T}_{2}: \mathrm{PIH} 202310 \%$ SC $20 \mathrm{~g}$ a.i/ha & 24.34 & 91.66 & 7.67 & 22.71 & 43.64 & 48.48 \\
\hline $\mathrm{T}_{3}$ : PIH $202310 \%$ SC $25 \mathrm{~g}$ a.i/ha & 24.12 & 88.81 & 10.85 & 24.59 & 45.71 & 53.45 \\
\hline $\mathrm{T}_{4}: \mathrm{PIH} 202310 \%$ SC $30 \mathrm{~g}$ a.i/ha & 23.93 & 83.47 & 6.34 & 24.14 & 46.14 & 48.56 \\
\hline $\mathrm{T}_{5}$ : PIH $202310 \%$ SC $60 \mathrm{~g}$ a.i/ha & 23.76 & 89.26 & 7.46 & 23.63 & 48.91 & 59.34 \\
\hline $\mathrm{T}_{6}:$ Almix $20 \% \mathrm{WP} 04 \mathrm{~g}$ a.i $/ \mathrm{ha}$ & 23.89 & 96.03 & 37.99 & 22.15 & 33.60 & 51.17 \\
\hline $\mathrm{T}_{7}:$ Unweeded check & 24.02 & 65.22 & 78.00 & 21.87 & 25.66 & 52.31 \\
\hline $\mathrm{T}_{8}$ : Hand weeding (once) & 24.46 & 102.16 & - & 21.57 & 45.28 & 51.58 \\
\hline $\mathrm{SEm} \pm$ & 0.40 & 2.50 & - & 0.65 & 2.29 & 3.02 \\
\hline $\mathrm{CD}(5 \%)$ & 1.23 & 7.61 & - & 1.99 & 6.96 & 9.16 \\
\hline
\end{tabular}

\section{Weed index}

Weed index indicate the reduction in yield due to weed competition as compared to the maximum attained grain yield. Weed index had remarkably influenced by weed management practices. Maximum weed index were noticed under unweeded control $(78.00 \%)$ where as minimum weed index were registered under PIH 2023 10\% SC $30 \mathrm{~g}$ a.i/ha $(6.34 \%)$ over rest of the treatment.

\section{References}

1. Narwal S, Singh S, Panwar KS, Malik RK. Performance of acetachlor and anilofos + ethoxysulfuron for weed control in transplanted rice (Oryza sativa L.). Indian J. Agronomy. 2002; 47(1):67-71.

2. Tiwari BK, Mathew R, Dwivedi RK, Shrivas DN. Integrated weed management in direct-seeded puddled rice (Oryza sativa). Extended Summaries Vol 2. $2^{\text {nd }}$ International Agronomy Congress, Nov. 26-30, New Delhi, India, 2002; 26(30):935-937.

3. Dhiman SD, Nandal DP. Integrated weed management in direct seeded puddle rice. Indian J. Weed Sci. 1997; 28(2):164-166.

4. Gogoi AK. Weed control in late transplanted lowland rice. Indian J. Agron. 1998; 43(2):298-299.

5. Rekha KB, Raju MS, Reddy MD. Effect of herbicides on weed growth, grain yield and Nutrient uptake in Rainfed low land rice. Indian Journal of Weed Science. 2003; 35(1-2):121-122. 